\title{
Hubungan enuresis dengan kejadian leukosituria pada siswa sekolah dasar
}

\author{
${ }^{1}$ Angie G. Roring \\ ${ }^{2}$ Adrian Umboh \\ ${ }^{2}$ Rocky Wilar
}

\author{
${ }^{1}$ Kandidat Skripsi Fakultas Kedokteran Universitas Sam Ratulangi Manado \\ ${ }^{2}$ Bagian Ilmu Kesehatan Anak Fakultas Kedokteran Universitas Sam Ratulangi Manado \\ Email: AngieR@gmail.com
}

\begin{abstract}
Enuresis refers to the involuntary excretion of urine that occurs during urination which is expected to have already been attained. Enuresis is divided into nocturnal enuresis and diurnal enuresis. Nocturnal enuresis (sleep wetting) is enuresis which occurs at night while enuresis diurnal (awake wetting) is enuresis which occurs during the day. The presence of leukocytes in urine that exceeds the normal value is called leukocyturia which is a sign of inflammation of the urinary tract (kidneys, ureter, bladder, and urethra). This study aimed to obtain the relationship between leukocyturia and enuresis among primary school students aged 5-10 years in SDN 4 and SDN 8 Wawalintouan Tondano. This was an observational analytical study with a cross sectional approach. Samples were obtained by using purposive sampling method. There were 60 urine samples of children of SDN 4 and SDN 8 Wawalintouan, Tondano. The results showed that of the 60 students, there were 34 males (56.7\%) and 26 females (43.3\%). Based on gender, there were 29 males (61.7\%) with negative leukocyturia and 5 males (38.5\%) with positive leukocyturia; among females there were 18 females (38.3\%) with negative leukocyturia and 8 females $(61,5 \%)$ with positive leukocyturia Based on enuresis, the distribution of leukocyturia showed 7 students $(53,8 \%)$ with enuresis and positive leukocyturia, meanwhile of those without enuresis there were 6 students $(46,2 \%)$ with positive leukocyturia. Conclusion: There was no relationship between the incidence of enuresis and leukocyturia among primary school students aged 5-10 years in SDN 4 and SDN 8 Wawalintouan Tondano.
\end{abstract}

Keywords: enuresis,leukosituria,urinalysis.

\begin{abstract}
Abstrak: Enuresis merupakan pengeluaran air kemih yang tidak disadari yang terjadi pada saat proses berkemih diharapkan sudah tercapai. Enuresis di bagi atas enuresis nokturnal dan enuresis diurnal. Enuresis nokturnal (sleep wetting) merupakan enuresis yang terjadi pada malam hari sedangkan enuresis diurnal (awake wetting) adalah enuresis yang terjadi pada siang hari. Terdapatnya leukosit dalam urin melebihi nilai normal disebut leukosituri yang merupakan salah satu tanda adanya peradangan pada saluran kemih (mencakup ginjal, ureter, kandung kemih, dan uretra). Penelitian ini bertujuan untuk mengetahui hubungan antara enuresis dengan kejadian leukosituria pada siswa sekolah dasar usia 5-10 tahun di SDN 4 dan SDN 8 Wawalintouan Tondano. Jenis penelitian ini analitik observasional dengan desain potong lintang. Sampel diperoleh dengan metode purposive sampling yang dilaksanakan dengan mengambil sampel urin anak-anak sekolah dasar di SDN 4 dan SDN 8 Wawalintouan Tondano. Hasil penelitian memperlihatkan dari 60 sampel terdapat 34 anak laki-laki (56,7\%) dan 26 anak perempuan (43,3\%). Dari distribusi leukosituria berdasarkan jenis kelamin didapatkan anak laki-laki dengan leukosituria negatif berjumlah 29 anak (61,7\%) dan dengan leukosituria positif 5 anak (38,5\%), sedangkan anak perempuan dengan leukosituria negatif berjumlah 18 anak (38,3\%) dan yang leukosituria positif 8 anak $(61,5 \%)$. Distribusi leukosituria berdasarkan enuresis didapatkan 7 anak (53,8\%) yang enuresis dengan
\end{abstract}


leukosituria positif, sedangkan yang tidak enuresis didapatkan 6 anak (46,2\%) dengan leukosituria positif. Simpulan: Tidak terdapat hubungan antara enuresis dengan kejadian leukosituria pada siswa sekolah sekolah dasar usia 5-10 tahun di SDN 4 dan SDN 8 Wawalintouan Tondano.

Kata kunci: enuresis, leukosituria, urinalisis

Enuresis atau yang sering dikenal dengan mengompol adalah pengeluaran air kemih yang tidak disadari yang terjadi pada saat pengendalian proses berkemih dianggap sudah tercapai. ${ }^{1}$ Enuresis fungsional adalah pengeluaran urin involunter pada waktu siang atau malam hari pada anak yang berumur lebih dari 4 tahun, tanpa adanya kelainan fisik atau penyakit organik. ${ }^{2}$ Enuresis nokturnal (sleep wetting, bed wetting) adalah enuresis yang tejadi pada malam hari, sedangkan enuresis diurnal (awake wetting) adalah enuesis pada siang hari. Kriteria untuk enuresis nokturnal masih banyak berbeda di antara para pakar, namun pada umumnya batasan yang sering dipakai ialah apabila enuresis pada malam hari menetap lebih dari dua kali dalam sebulan pada anak yang berumur di atas 5 tahun. ${ }^{3}$

Penelitian epidemiologi di luar negeri menunjukkan pada usia 6-7 tahun 80\% anak secara penuh dapat mengendalikan kandung kemihnya, sedangkan 20\% lagi mengalami enuresis nokturnal, enuresis diurnal atau keduanya. ${ }^{4}$

Mengendalikan kandung kemih pada siang hari lebih dahulu dikuasai anak sebelum mereka bisa mengendalikan kandung kemih pada malam hari. Kebanyakan anak berhenti mengompol pada malam hari. Kebanyakan anak berhenti mengompol pada siang hari begitu berusia 3 tahun dan berhenti mengompol pada malam hari begitu mencapai usia sekolah. Hal ini sangat bervariasi, dan anak-anak bisa saja mengompol, baik siang maupun malam, sampai mereka berusia 7 atau 8 tahun. ${ }^{5}$

Suatu keadaan di mana terdapatnya leukosit dalam urin yang melebihi nilai normal di sebut leukosituri. Leukosituri merupakan salah satu tanda adanya peradangan pada saluran kemih (mencakup ginjal, ureter, kandung kemih, dan uretra). ${ }^{6}$ Infeksi saluran kemih (ISK) merupakan penyakit yang relatif sering pada anak. Prevalensi ISK pada neonatus berkisar antara 0,1\% hingga $1 \%$, dan meningkat menjadi $14 \%$ pada neonatus dengan demam, dan 5,3\% pada bayi. Pada bayi asimtomatik bakteriuria didapatkan pada $0,3 \%$ hingga $0,4 \%$. Risiko ISK pada anak sebelum pubertas yaitu 3-5\% pada anak perempuan dan 1-2\% pada anak lakilaki. Pada anak dengan demam berumur kurang dari 2 tahun ditemukan prevalensi ISK 3-5\%. ${ }^{7}$

ISK dan enuresis memiliki hubungan yang sangat erat. ISK merupakan salah satu faktor penyebab dari enuresis. ISK adalah infeksi akibat berkembangbiaknya mikroorganisme di dalam saluran kemih. Dalam keadaan normal air kemih tidak mengandung bakteri, virus. atau mikroorganisme yang lain. ${ }^{8}$

Penelitian ini bertujuan untuk mengetahui adanya hubungan antara enuresis dengan leukosituria pada siswa sekolah dasar menggunakan hasil urinalisis siswa-siswi sekolah dasar yang diketahui masih ngompol (enuresis), baik enuresis nokturnal maupun diurnal. Penelitian ini dilakukan di SDN 4 dan SDN 8 Wawalintouan Tondano.

\section{METODE PENELITIAN}

Jenis penelitian ini analitik observasional dengan desain potong lintang yang dilakukan pada bulan November 2015 sampai Desember 2015 pada anak SDN 4 dan 8 Wawalintouan Tondano usia 5 sampai 10 tahun dengan menggunakan metode purposive sampling. Subjek penelitian berjumlah 60 terdiri dari 30 anak yang enuresis dan 30 anak sebagai kontrol. Pengambilan sampel urin dilaksanakan setelah informed consent ditandatangani 
oleh orang tua responden dalam hal ini yang bersedia dilakukan pengambilan sampel urin dan kemudian diperiksa di laboratorium. Sampel yang dipilih sesuai dengan kriteria inklusi dan eksklusi dan didapat sebanyak 60 sampel urin. Hasil penelitian diolah menggunakan Microsoft Excel dan SPSS 22.

\section{HASIL PENELITIAN}

Penelitian ini dilakukan kpada siswasiswi SDN 4 dan 8 dengan jumlah subjek penelitian yang masih enuresis dan yang tidak enuresis sebagai kontrol masingmasing berjumlah 30 anak usia responden berkisar antara 5-10 tahun, dan yang terbanyak berusia 10 tahun sebanyak 14 orang (23,3\%). Distribusi kejadian leukosituria pada responden berdasarkan jenis kelamin baik anak yang enuresis maupun yang tidak enuresis diperoleh jumlah anak laki-laki dengan leukosituria negatif sebanyak 29 anak (61,7\%), dan anak laki-laki dengan leukosituria positif ialah 5 anak (38,5\%). Pada anak perempuan diperoleh jumlah sebanyak 18 anak (38,3\%) dengan leukosituria negatif, dan 8 anak (61,5\%) dengan leukosituria positif (Tabel 1).

Distribusi perbandingan kejadian leukosituria pada anak yang enuresis dan yang tidak diperoleh data 7 anak (53,8\%) yang enuresis dengan leukosituria positif dan yang negatif 23 anak (49,0\%), sedangkan yang tidak enuresis dengan leukosituria positif 6 anak (46,2\%) dan yang negatif 24 anak (51,0\%). Berdasarkan kuesioner didapatkan bahwa dari 30 anak yang enuresis, 29 anak ngompol pada malam hari (enuresis nokturnal) dan 1 anak ngompol pada siang dan malam hari (enuresis nokturnal dan diurnal) (Tabel 2)

Tabel 1. Distribusi kejadian leukosituria berdasarkan jenis kelamin

\begin{tabular}{ccccccc}
\hline Jenis kelamin & \multicolumn{2}{c}{ Leukosituria negatif } & \multicolumn{2}{c}{ Leukosituria positif } & \multicolumn{2}{c}{ Total } \\
& $\mathrm{N}$ & $\%$ & $\mathrm{n}$ & $\%$ & $\mathrm{~N}$ & $\%$ \\
\hline Laki-laki & 29 & 61,7 & 5 & 38,5 & 34 & 56,7 \\
Perempuan & 18 & 38,3 & 8 & 61,5 & 26 & 43,3 \\
Total & 47 & 100 & 13 & 100 & 60 & 100 \\
\hline
\end{tabular}

Tabel 2. Distribusi kejadian leukosituria berdasarkan enuresis

\begin{tabular}{cccllll}
\hline \multirow{2}{*}{ Enuresis } & \multicolumn{2}{c}{ Leukosituria negatif } & \multicolumn{2}{c}{ Leukosituria } & \multicolumn{2}{l}{ Total } \\
& $\mathrm{N}$ & $\%$ & $\mathrm{~N}$ & $\%$ & $\mathrm{~N}$ & $\%$ \\
\hline Ya & 23 & 49,0 & 7 & 53,8 & 30 & 50 \\
Tidak & 24 & 51,0 & 6 & 46,2 & 30 & 50 \\
Total & 47 & 100 & 13 & 100 & 60 & 100 \\
\hline
\end{tabular}

Hasil analisis statistik hubungan antara enuresis dengan kejadian leukosituria menggunakan uji statistik Chi-Square yang menghasilkan nilai $p=0,377$. Hasil ini menunjukkan faktor enuresis tidak memengaruhi kejadian leukosituria pada siswa sekolah dasar.

\section{BAHASAN}

Dari penelitian yang dilakukan pada 60 anak sekolah dasar usia 5-10 tahun di Kelurahan Wawalintouan Kecamatan
Tondano Barat khususnya di SDN 4 dan SDN 8 Tondano didapatkan 34 anak dengan jenis kelamin laki-laki dan 26 anak jenis kelamin perempuan. Sebagian besar berada pada golongan usia 10 tahun dengan jumlah 14 responden (23,3\%), usia 5 dan 9 tahun dengan jumlah masing-masing 12 responden (20\%), usia 6 tahun 10 responden (16,7\%), usia 8 tahun 7 responden $(11,7 \%)$ dan usia 7 tahun sebanyak 5 responden (8,3\%). Berdasarkan jenis kelamin di ketahui bahwa anak laki- 
laki lebih banyak menderita enuresis (60\%) dibandingkan anak perempuan (40\%). Dari keseluruhan sampel yang didapat anak perempuan yang mengalami leukosituria positif sebanyak 8 anak (61,5\%), sedangkan laki-laki sebnayak 5 anak (38,5\%). Dari data di atas didapatkan bahwa distribusi kejadian leukosituria pada anak perempuan lebih banyak dari pada anak laki-laki berdasarkan perhitungan jumlah leukosit >5/LPB. Dari data tersebut peneliti menduga bahwa tingginya angka kejadian leukosituria pada anak perempuan karena salah satu faktor anatomi di mana anak perempuan cenderung memiliki uretra lebih pendek dibandingkan laki-laki. ${ }^{9}$

Pada penelitian ini diketahui bahwa anak yang mengalami enuresis paling banyak berada pada umur 5 tahun dengan jumlah 9 anak, umur 6 tahun 6 anak, umur 9 tahun 5 anak, umur 10 tahun 5 anak, umur 7 tahun 3 anak dan yang paling sedikit golongan umur 8 tahun sebanyak 2 anak. Penelitian ini berbanding terbalik dengan penelitian yang dilakukan oleh Alrashed dan Bataineh pada anak usia 5-10 tahun yang menemukan prevalensi enuresis terbesar pada umur 7 tahun dengan jumlah 16 orang $(25,8 \%){ }^{10}$ Angka kejadian enuresis di berbagai negara bervariasi. Hasil survei di Eropa dan Amerika Utara menunjukkan bahwa 15-20\% anak berumur 5 tahun, 7\% anak berumur 10 tahun, dan 12\% anak berumur 15 tahun mengalami enuresis. ${ }^{4}$ Dari 30 sampel anak yang mengalami enuresis didapat bahwa semua anak mengompol pada malam hari (nokturnal enuresis). Kriteria untuk enuresis nokturnal masih banyak berbeda di antara para pakar, namun pada umumnya batasan yang sering dipakai ialah bila enuresis pada malam hari menetap lebih dari dua kali dalam sebulan pada anak yang berumur di atas lima tahun. Suatu penelitian menunjukkan bahwa $80 \%$ mengalami enuresis nokturnal dan $20 \%$ mengalami enuresis diurnal.

Dari penelitian ini juga ditemukan anak yang enuresis dan tidak pernah diajarkan toilet training berjumlah 12 anak (40\%) lebih banyak dibandingkan anak yang tidak enuresis 6 anak (20\%). Hal ini sesuai dengan suatu studi yang mengatakan bahwa anak yang tidak mengalami enuresis toilet trainingnya lebih baik (85,7\%) sedangkan anak yang masih mengalami enuresis toilet trainingnya kurang baik (80,0\%). ${ }^{11}$

Menurut awal terjadinya, enuresis di bagi menjadi enuresis primer yaitu enuresis terjadi sejak lahir dan tidak pernah ada periode normal dalam pengontrolan buang air kemih, sedangkan enuresis sekunder terjadi setelah 6 bulan dari periode setelah kontrol pengosongan air kemih sudah normal. Gejala klinik ISK pada anak sangat bervariasi, ditentukan oleh intensitas reaksi peradangan, letak infeksi (ISK atas dan ISK bawah) serta umur pasien. Sebagian ISK pada anak merupakan ISK asimtomatik dan umumnya ditemukan pada anak usia sekolah, terutama anak perempuan. Pemeriksaan urinalisis meliputi leukosituria, nitrit, leukosit esterase, protein, dan darah. Leukosituria merupakan petunjuk kemungkinan adanya bakteriuria, tetapi tidak di pakai sebagai patokan ada tidaknya ISK. Leukosituria biasanya ditemukan pada anak dengan ISK (80-90\%) di setiap episode ISK simtomatik, tetapi tidak adanya leukosituria tidak menyingkirkan ISK. ${ }^{12}$

\section{SIMPULAN}

Berdasarkan hasil penelitian yang dilakukan pada siswa sekolah dasar SDN 4 dan SDN 8 Wawalintouan Tondano dapat disimpulkan bahwa tidak terdapat hubungan antara enuresis dengan kejadian leukosituria pada siswa sekolah dasar usia 5-10 tahun di SDN 4 dan SDN 8 Wawalintouan Tondano.

\section{UCAPAN TERIMA KASIH}

Ucapan terima kasih ditujukan kepada Prof. Dr. dr. Sarah.M. Warouw, Sp.A(K), dr. Jose Mandei, Sp.A(K), kepala sekolah, guru, orang tua dan murid SDN 4 dan SDN 8 Tondano, serta semua pihak yang terlibat baik secara langsung dan tidak langsung dalam penelitian ini.

\section{DAFTAR PUSTAKA}

1. Rushton HG. Enuresis. In: Kher KK, Makker SP, editor. Clinical pediatric 
nephrology. New York: McGrawHill;, 1992; p. 399-419.

2. Markum AH. Enuresis fungsional. In: Markum AH, Ismael S, Akib A, Firmansyah A, Sastroasmoro S, editors. Buku ajar ilmu kesehatan anak (1st ed). Jakarta: FK UI, 1991; p.61-2.

3. Noer MS. Enuresis. Continuing education Ilmu Kesehatan Anak xxxvi Kapita Selekta Ilmu Kesehatan Anak vi; 2006 July 29-30. Surabaya: FK Unair RSU Dr. Soetomo Surabaya, 2006.

4. Daulay RS. Enuresis. Medan: USU digital library,2008.

5. Australian Government initiative. Childhood bed-wetting [pamphlet]. Melbourne: Department of Health and AgeingContinence Program; 2013.

6. Effendi I, Markum HMS. Pemeriksaan penunjang pada penyakit ginjal. In: Sudoyo AW, Setiyohadi B, Alwi I, Setiati S, penyunting. Buku ajar Ilmu Penyakit Dalam (1st ed). Jakarta: Pusat Penerbitan Departemen Ilmu Penyakit Dalam FKUI, 2006; p. 50512.

7. Pardede SO, Tambunan T, Alatas H, Trihono PPT, Hidayati EL. In: Konsensus infeksi saluran kemih pada anak. Jakarta: Ikatan Dokter Anak Indonesia, 2011.

8. Samirah, Darwati, Windarwati, Hardjoeno. Pola dan sensitivitas kuman di penderita saluran kemih. Indonesian Journal of Clinical Pathology and Medical Laboratory. 2006;12:110-3.

9. Fahimzad A, Taherian M, Dalirani R, Shamshiri A. Diaper Type as a Risk Factor in Urinary Tract Infection of Children. Iran Journal of Pediatr. 2010;20(1):97-100.

10. Alrashed KM, Bataineh HA. Frequency of enuresis in (5-10) years old in Tafila, Jordan. Shiraz E-Medical Journal. 2007;8:1-5.

11. Bastari A, Wahyuni S, Pranoto HH. HubunganToilet Training terhadap Enuresis pada Balita usia 3-5 tahun di PAUD Al-Koiriyyah Sukoharjo. 2015 di unduh dari: http://perpusnwu.web.id/karyailmiah/ documents/4540.pdf.

12. Tambunan $T$. Enuresis nocturnal pada anak. In: Tridjaja B, Trihono PP, Irfan EB, editors. Pediatric update 2005. Jakarta: IDAI Jaya, 2005; p. 11-20. 